Vol.25, No.2, Desember 2019

ISSN (p): 1693-590x, ISSN (e): 2686-4711

DOI: $10.36309 /$ goi.v25i2.109

\title{
Aplikasi AUB Chat Berbasis Android pada STMIK AUB Surakarta
}

\author{
Kristono ${ }^{1}$, Sutariyani ${ }^{2}$, Ayuk W A ${ }^{3}$ \\ ${ }^{123}$ Program Studi Sistem Informasi, STMIK AUB, Surakarta, Indonesia \\ e-mail: ${ }^{* 1}$ kristono@stmik-aub.ac.id, ${ }^{2}$ tari.yani@stmik-aub.ac.id, ${ }^{3}$ ayukwa@gmail.com
}

\begin{abstract}
Abstrak
Tujuan penelitian ini adalah membangun Aplikasi AUB Chat Berbasis Android pada STMIK AUB Surakarta. Dalam membangun sistem tersebut metode pendekatan yang digunakan adalah metode perancangan dengan menggunakan metode waterfall. Metode pengumpulan data dengan metode wawancara, metode observasi dan metode pustaka.Sebagai alat bantu analisis dan perancangan yang digunakan adalah flowchart, UML ( Unified Moddeling Languange ), dan Entity Relationship Diagram. Sedangkan bahasa pemograman pendukung yang digunakan adalah Android Studio versi 3.1., PHP, Java,dan My SQL sebagai database. Hasil dari penelitian ini adalah membuat suatu Aplikasi AUB Chat Berbasis Android pada STMIK AUB Surakarta untuk meningkatkan nilai Ujian.
\end{abstract}

Kata kunci: Aplikasi, AUB Chat berbasis Android pada STMIK AUB Surakarta, Android, PHP

\section{PENDAHULUAN}

Dosen dalam proses pembelajaran di STMIK AUB Surakarta terdapat kesulitan dalam menjalin komunikasi yang baik dengan mahasiswa dan sarana penyampaian tugas perkuliahan untuk dikerjakan mahasiswanya. Dosen kesulitan dalam membuat tugas baru maupun grup chating dengan mahasiswa. Tugas perkuliahan dan grup chatting tersebut akan diterima di tampilan halaman mahasiswa. Mahasiswa kesulitan untuk mendapat komunikasi dengan dosen pengampu dalam mengerjakan tugas dan berdiskusi. Pembelajaran di STMIK AUB Surakarta masih mengalami keterbatasan pada media komunikasi yang tidak memungkinkan orang bertatap muka pada area lokasi saat ini.

Sistem yang dibangun dirancang untuk membantu tugas dosen dalam menjalin komunikasi yang baik dengan mahasiswa dan sarana penyampaian tugas perkuliahan untuk dikerjakan mahasiswanya. Sistem ini bermula dari admin menginputkan data master yaitu data dosen, data mahasiswa dan data mata kuliah. Data tersebut untuk memudahkan dosen dan mahasiswa menggunakan aplikasi ini. Dosen akan dapat membuat tugas baru maupun grup chating dengan mahasiswa. Tugas dan grup tersebut akan diterima di tampilan halaman mahasiswa. Saat mendapatkan tugas, mahasiswa dapat mengerjakan tugas secara langsung di aplikasi tersebut. Media chatting untuk mengatasi keterbatasan pada media yang tidak memungkinkan orang bertatap muka pada area lokal saat ini dengan protokol yang digunakan yakni Extensible Messaging and Presence Protocol (XMPP).

\section{METODE PENELITIAN}

\subsection{Analisis Kebutuhan Informasi}

Aplikasi yang dibangun membutuhkan beberapa data yaitu data mata kuliah, data dosen, data mahasiswa dan data tugas kuliah untuk proses yang ada di aplikasi chating. Data mata kuliah digunakan untuk ketentuan tugas dari dosen. Data dosen berisi informasi identitas dosen

Received November 11, 2019; Revised November 25, 2019; Accepted December 9, 2019 
guna membuat akun dosen. Data mahasiswa berisi informasi identitas mahasiswa guna membuat akun mahasiswa. Data kulaih diisi oleh dosen untuk diterima oleh mahasiswa. Proses pengerjaan tugas menghasilkan keluaran berupa nilai mahasiswa.

\subsection{Analisis Kebutuhan Pengguna}

Aplikasi yang dibangun dijalankan oleh tiga user yaitu administrator, dosen dan mahasiswa. Administrator bertugas menginputkan data master yaitu data mata kulaih, data dosen dan data mahasiswa. Dosen mempunyai wewenang untuk membuat grub chating dan tugas perkuliahan. Mahasiswa dapat menggunakan aplikasi chating untuk kebutuhan perkuliahan dan mengerjakan tugas yang sudah diberikan dosen melalui aplikasi. Kemudian dosen akan menerima data nilai dari jawaban mahasiswa.

\subsection{Flowchart Sistem}

Sistem yang dibangun dirancang untuk membantu tugas dosen dalam menjalin komunikasi yang baik dengan mahasiswa dan sarana penyampaian tugas perkuliahan untuk dikerjakan mahasiswanya. Sistem ini bermula dari admin menginputkan data master yaitu data dosen, data mahasiswa dan data mata kuliah. Data tersebut untuk memudahkan dosen dan mahasiswa menggunakan aplikasi ini. Dosen akan dapat membuat tugas baru maupun grup chating dengan mahasiswa. Tugas dan grup tersebut akan diterima di tampilan halaman mahasiswa. Saat mendapatkan tugas, mahasiswa dapat mengerjakan tugas secara langsung di aplikasi tersebut. Kemudian sistem akan memproses jawaban dan otomatis menghasilkan nilai. Dosen akan menerima nilai hasil tugas yang dikerjakan mahasiswa.

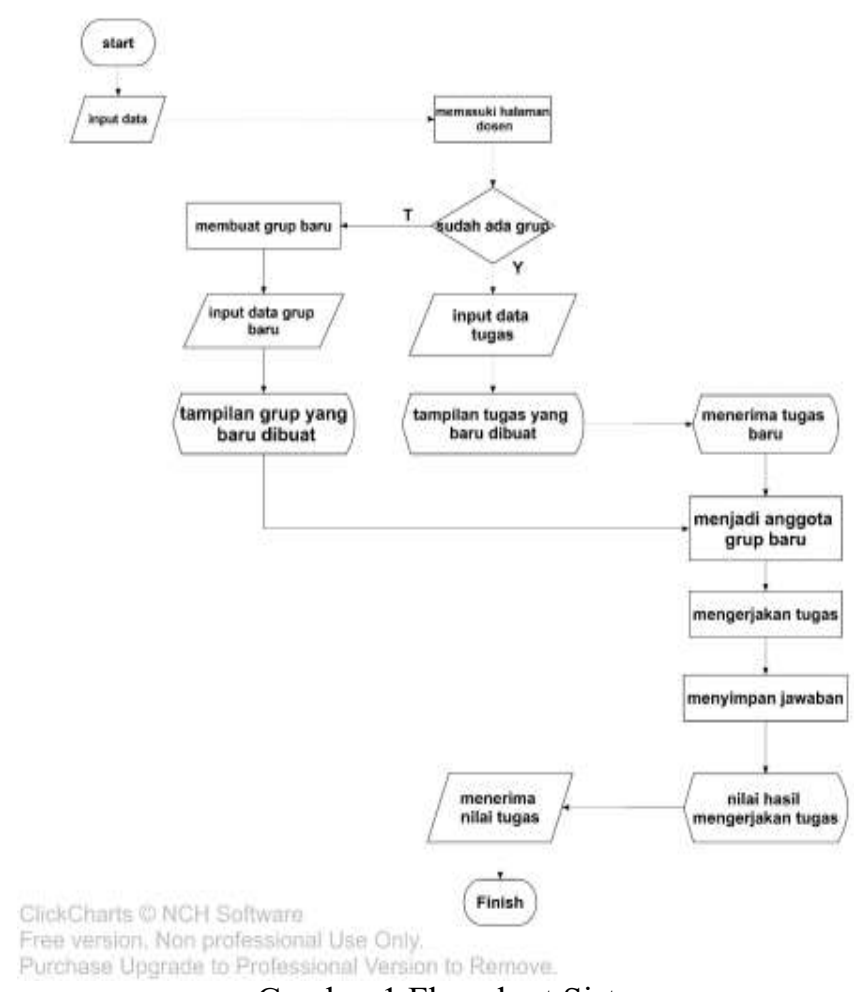

\subsection{Diagram Konteks}

Gambar 1 Flowchart Sistem 


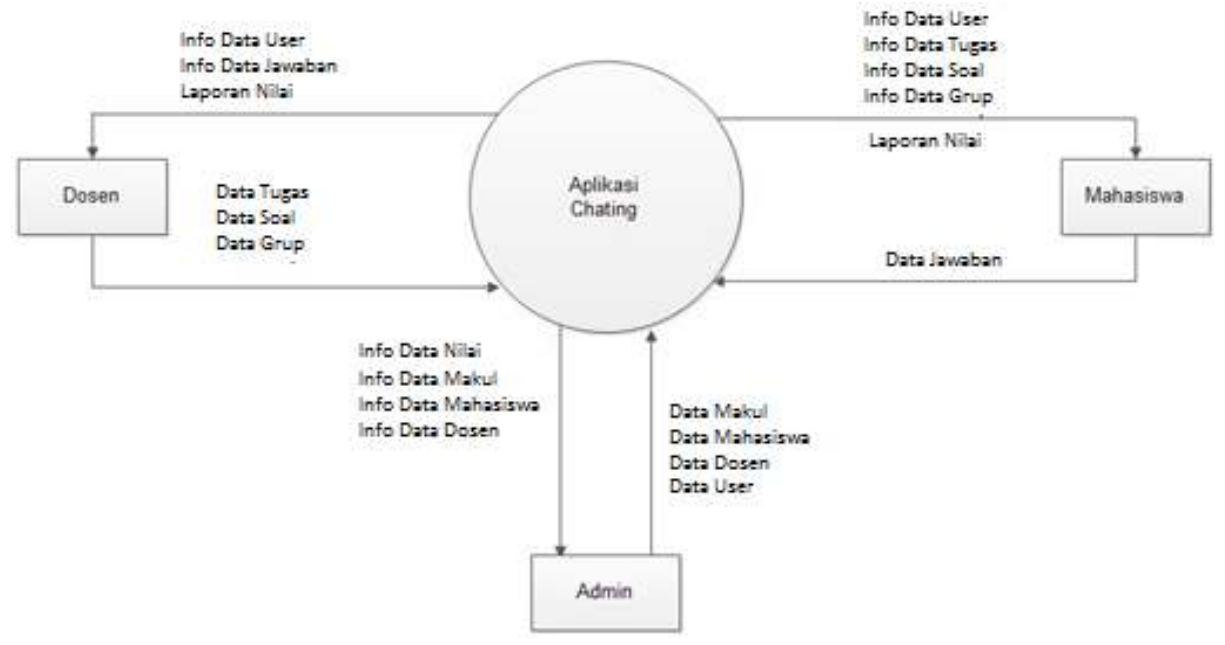

\subsection{Data Flow Diagram Level 0 \\ Gambar 2 Diagram Konteks}

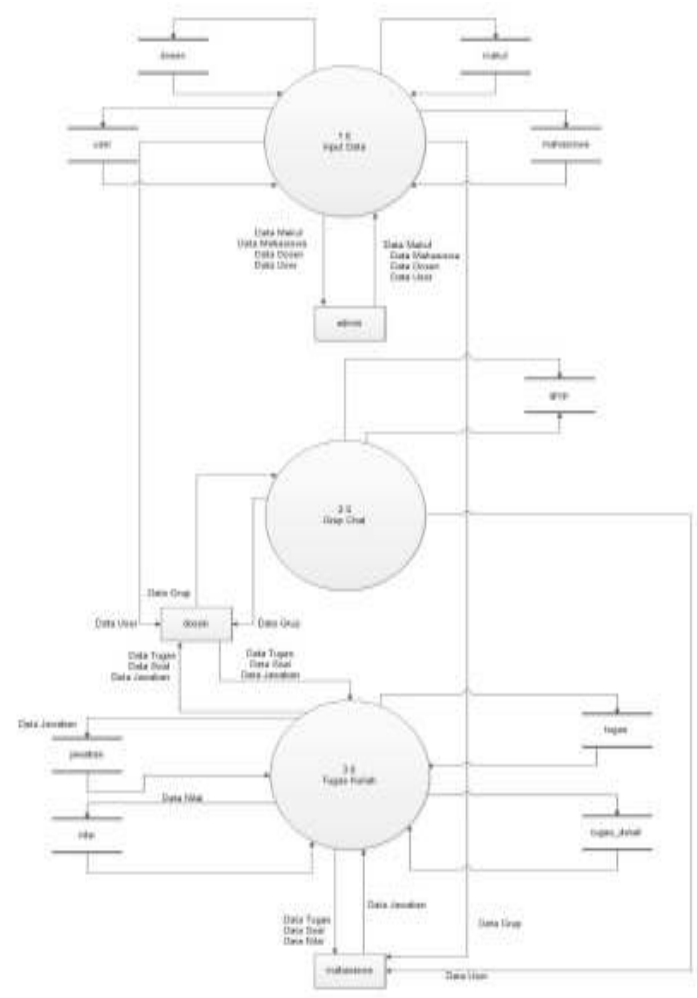

Gambar 3 Data Flow Diagram Level 0

Pada gambar 3 menjelaskan terdapat empat proses yaitu proses input data, pembuatan grup chat, dan pembuatan tugas kuliah.

2.6 Relasi Antar Tabel

GO INFOTECH: JURNAL ILMIAH STMIK AUB Vol. 25, No. 2, Desember 2019: 112-121 


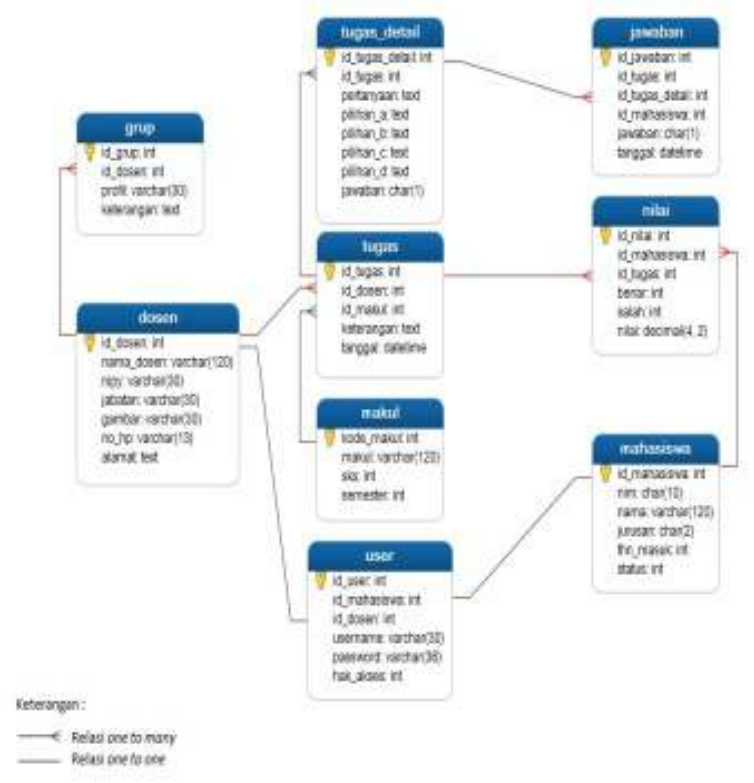

Gambar 4 Relasi Antar Tabel

\section{HASIL DAN PEMBAHASAN}

\subsection{Hasil Antar muka Aplikasi}

1. Halaman Admin

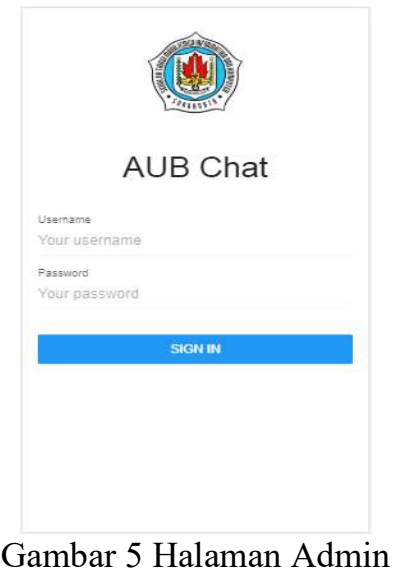

2. Halaman Utama

Gambar 5 Halaman Admin 
3. Halaman Data Mahasiswa

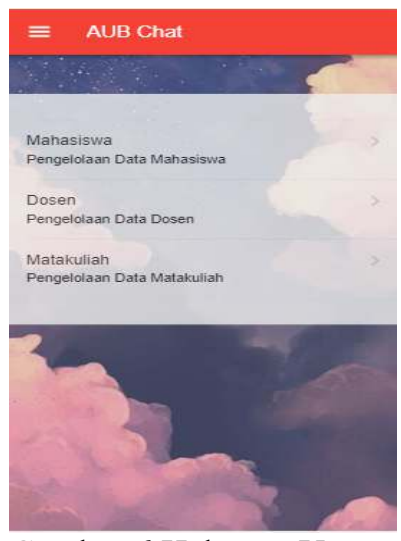

Gambar 6 Halaman Utama

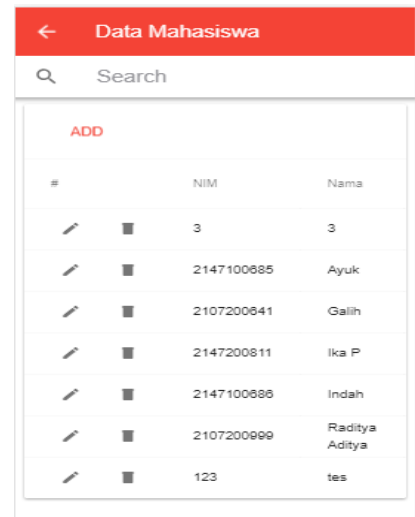

Gambar 7 Halaman Data Mahasiswa

Admin mempunyai wewenang untuk mengelola data mahasiswa. Admin dapat menambahkan data mahasiswa dan menghapus data mahasiswa. Sistem menampilkan semua data mahasiswa pada halaman data mahasiswa.

4. Halaman Data Dosen

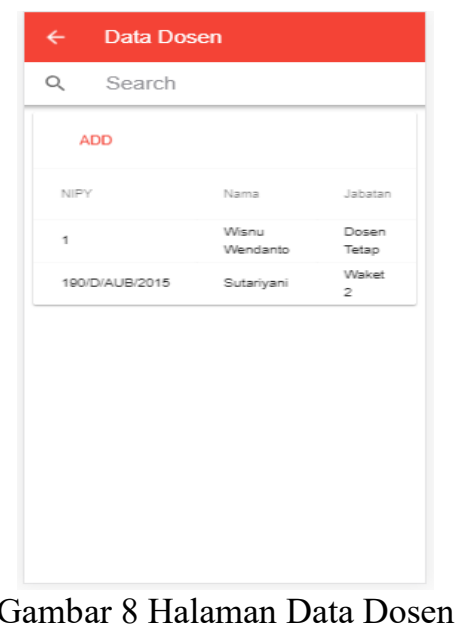

Admin mempunyai hak akses untuk mengelola data dosen. Admin dapat menambahkan data dosen dengan mengklik ADD dan menghapus data dosen dengan mengklik Remove. Pada halaman ini menampilkan semua data dosen

GO INFOTECH: JURNAL ILMIAH STMIK AUB Vol. 25, No. 2, Desember 2019: 112-121 
5. Halaman Chat sebagai Dosen

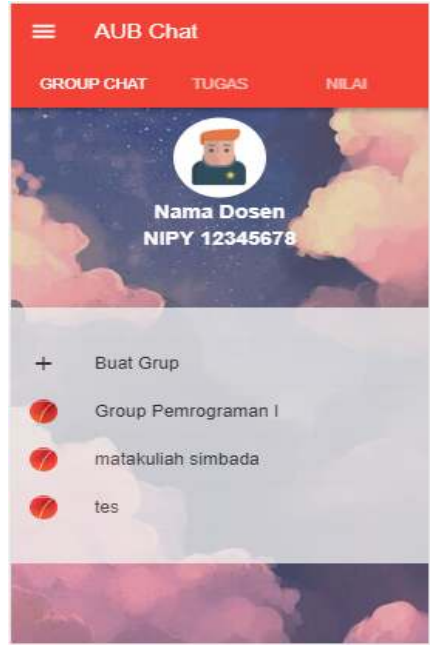

Gambar 9 Halaman Chat sebagai Dosen

Gambar 9 aplikasi AUB Chat menampilkan dua menu untuk dosen, yang pertama menu Group Chat. Dosen dapat melihat identitas diri dan nama-nama group yang diikuti. Dosen dapat menambahkan melalui aplikasi ini dengan mengklik tombol Buat Group.

6. Halaman Tugas Dosen

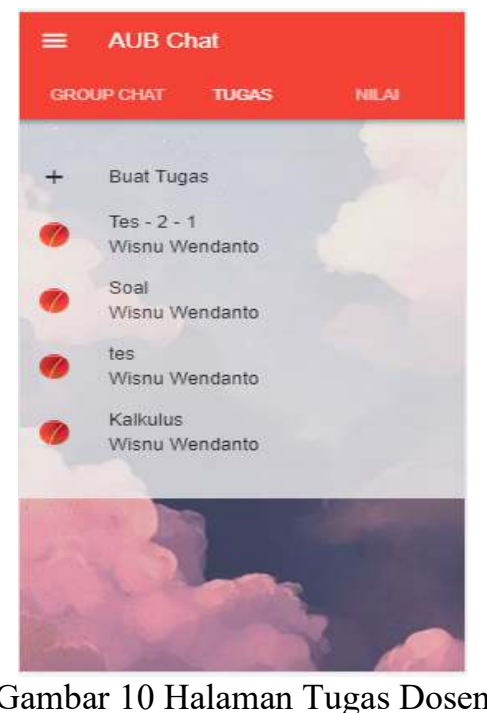

Gambar 10 menu kedua yaitu menu tugas. Dosen dapat melihat daftar nama tugas yang sudah dibuat. Pada halaman ini, dosen dapat membuat tugas baru untuk mahasiwa dengan mengklik Buat Tugas.

7. Halaman Group 
8. Halaman Tugas
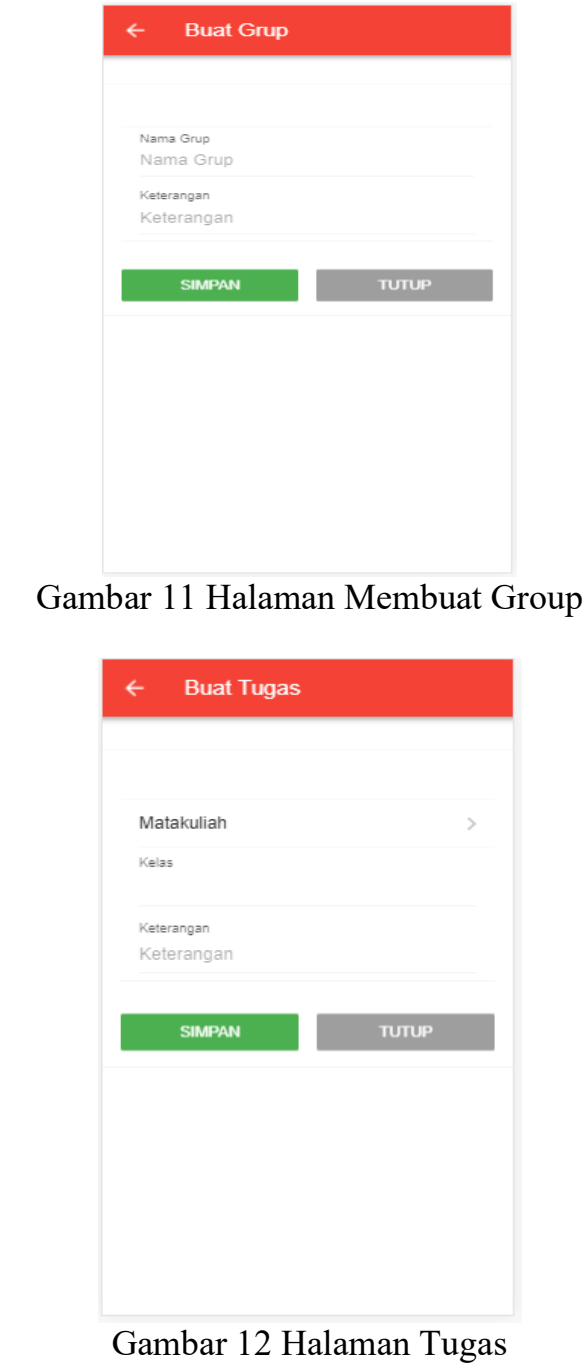

Setelah dosen mengklik tombol Buat Tugas, sistem akan menampilkan halaman buat tugas. Dosen mengisi nama tugas yang akan diberikan sesuai mata kuliah yang diampu. Klik Simpan untuk menyimpan data yang ditambahkan.

9. Halaman Entri Soal

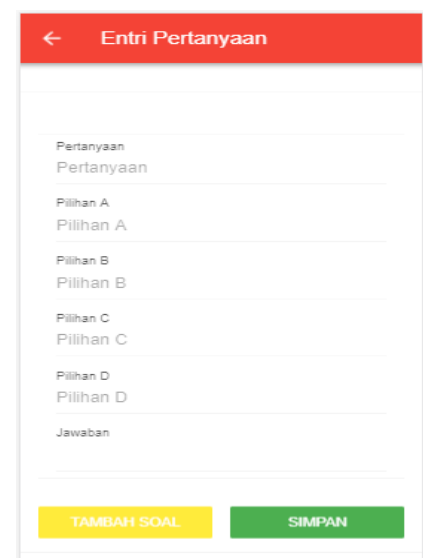

Gambar 13 Halaman Entri Soal

Dosen mengisi pertanyaan yang akan diberikan mahasiswa, disertai pilihan jawaban a,

GO INFOTECH: JURNAL ILMIAH STMIK AUB Vol. 25, No. 2, Desember 2019: 112-121 
jawaban b, jawaban c dan jawaban d. Dosen juga memberikn kunci jawaban yang benar untuk proses penilaian.

10. Halaman Group Chat Mahasiswa

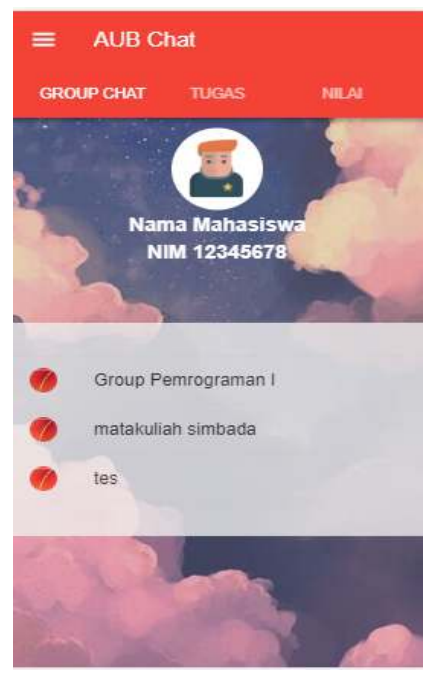

Gambar 14 Halaman Group Chat Mahasiswa

11. Halaman Tugas Mahasiswa

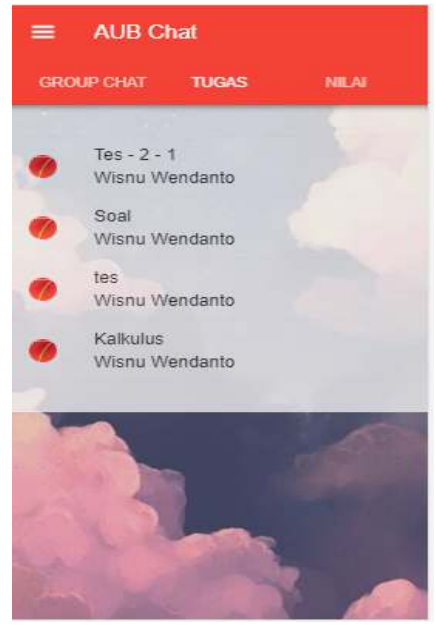

Gambar 15 Halaman Tugas Mahasiswa

Pada gambar 15 menu yang kedua yaitu menu tugas. Aplikasi ini menampilkan daftar nama tugas untuk dikerjakan mahasiswa.

12. Halaman Nilai Mahasiswa

Halaman nilai mahasiswa menampilkan nilai hasil dari tugas mahasiswa. 


\subsection{Pembahasan}

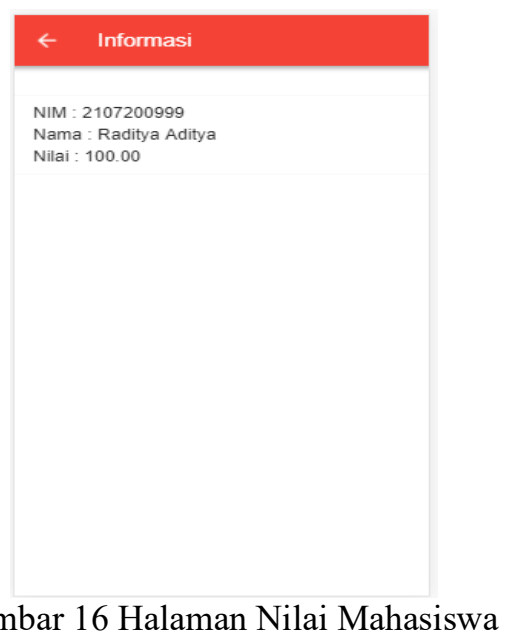

Manual program ini akan dijelaskan bagaimana cara penggunaan sistem yang telah dibuat. Berikut penjelasan dari fitur atau menu yang telah dibuat :

a. Saat sistem akan digunakan, admin menyimpan data master yaitu data dosen, data mahasiswa, data mata kuliah dan data user. Admin menambahkan setiap data yang baru masuk sehingga dosen maupun mahasiswa baru dapat menggunakan sistem ini.

b. Dosen menginputkan data user yang sudah didaftarkan untuk memasuki halaman dosen. Dosen mempunyai hak akses untuk membuat grup sesuai mata kuliah dan membuat tugas kuliah untuk mahasiswa.

Grup mata kuliah dan tugas dari dosen dapat ditampilkan di halaman mahasiswa. Mahasiswa memperoleh informasi mengenai kegiatan perkuliahan dari grup yang diikuti. Selain itu, mahasiswa yang sudah menerima tugas dari dosen, dapat mengerjakan tugas melalui aplikasi secara langsung. Menjawab pada kolom yang sudah disediakan. Sistem akan memproses jawaban dan menghasilkan nilai tugas untuk diberikan kepada dosen.

\section{KESIMPULAN}

Pengembangan sistem menggunakan bahasa pemrograman pendukung Android Studio Versi 3.1., PHP, Java dan MySQL sebagai pengolahan database. Sistem ini bisa melakukan pengolahan data mata kuliah, data soal, data mahasiswa, hasil nilai mahasiswa dan pembahasan soal. Adanya aplikasi AUB chat berbasis android pada STMIK AUB Surakarta memberikan media baru bagi mahasiswa dalam menyediakan soal. Selain itu juga dilengkapi dengan pengolahan nilai mhasiswa, yang bisa dijadikan sebagai tolak ukur kemampuan mahasiswa. Hasil dari penelitian ini adalah membuat suatu aplikas AUB chat berbasis android yang dapat membantu mahasiswa STMIK AUB Surakarta untuk meningkatkan belajar dan semangat mengerjakan tugas kuliah.

\section{DAFTAR PUSTAKA}

[1] Anonim. 2016. Buku Pedoman Penyusunan Skripsi. Surakarta: STMIK AUB Surakarta.

[2] Gat. 2015. Integrasi Fingerprint System dengan Real Time Absensi Dosen Berbasis Web. Cogito Smart Journal. ISSN: 2541, Volume 2, Nomor 2, Halaman 135-146. http://www.ejurnal.com/2017/10/integrasi-fingerprint-system-dengan.html?m=1.Diakses pada tanggal 02 Maret 2018.

[3] Hermawan S, Stephanus. 2011. Mudah Membuat Aplikasi Android. Yogyakarta: Andi.

GO INFOTECH: JURNAL ILMIAH STMIK AUB Vol. 25, No. 2, Desember 2019: 112-121 
[4] Irawan, dkk. 2015. Presensi Sidik Jari (Fingerprint) Berbasis Web Service. Jurnal Fakultas MIPA Universitas Mulawarnman, Volume 1, Nomor 1. Samarinda. http://fmipa.unmul.ac.id./files/docs/Jurnal-Adi\%20Irawan.pdf.Diakses pada tanggal 02 Juni 2018.

[5] Jogiyanto, H. 2005. Anaisis dan Desain Sistem Informasi. Yogyakarta: Andi Offset.

[6] Kristanto, Andri. 2003. Perancangan Sistem Informasi dan Aplikasinya. Jakarta: Gava Media.

[7] Parlika. Rizky. Dkk. 2014. Sistem Absensi Sidik Jari Terintegrasi Sms Gateway Berbasis Dekstop Menggunakan Visual Basic dan Mysql. Jurnal Informatika. 9 (2): 7. http://eprints.upnjatim.ac.id. Diakses pada tanggal 02 Maret 2018.

[8] Pressman, Roger. 2010. Rekayasa Perangkat Lunak Pedekatan Praktisi. Yogyakarta: Andi.

[9] Ragil, Wukil. 2010. Pedoman Sosialisasi Prosedur Operasi Standar. Jakarta: Mitra Wacana Media.

[10] Saputro, R.D dan Hartanto, A.D. 2013. Perancangan Sistem Informasi Presensi Menggunakan Visual Basic Pada Jogja Fitnes. Jurnal Ilmiah DASI, ISSN: 1411-3201, Volume $\quad 14, \quad$ Nomor $04, \quad$ Halaman 44-48. http://ojs.amikom.ac.id/index.php/dasi/article/download/143/128/. Diakses pada tanggal 22 Juli 2018.

[11] Sandi, Mulyana. 2014. Bikin Website dengan Aplikasi-aplikasi Gratis Cepat, Mudah \& Murah. Yogyakarta: MediaKom.

[12] Sunyoto, Andi. 2007. Ajax Membangun Web dengan Teknologi Asynchronouse JavaScript dan XML. Yogyakarta: CV. Andi Offset.

[13] Wikipedia Bahasa Indonesia. 2017. Pengertian Aplikasi. http://id.m.wikipedia.org/wiki/Aplikasi. Diakses pada tanggal 01 Juni 2018.

[14] Winardi. 2006. Penentuan Posisi dengan GPS untuk Survey Terumbu Karang. Puslit Oseanografi-LIPI. http://www.coremap.or.id/download/GPS.pdf. Diakses pada tanggal 01 Juni 2018. 